\title{
Internal education quality evaluation as a factor of development of engineering education quality in Russia
}

\author{
Antoniy Shvindt ${ }^{1}$, and Ivan Nikanorov ${ }^{1, *}$ \\ ${ }^{1}$ Education Quality commission of Youth affairs Council of Ministry of Education and Science of the \\ Russian Federation, 115184 Moscow, Russian Federation
}

\begin{abstract}
In the paper, general approaches to evaluation of quality of engineering education in Russia, stated by expert community, are considered. The authors arrived at the conclusion that attention to internal evaluation mechanism of the education quality in Russian normative framework of higher education system is insufficient, as compared to European higher education practices. A pattern of involving the students in the internal evaluation of higher education quality is submitted to be a tool to develop the quality of engineering education. The pattern is been piloting in the framework of All-Russian project "Involving of Students of Higher Educational Institutions in Evaluation and Development of Education Quality "High-Quality Education".
\end{abstract}

\section{Introduction}

Development of higher engineering education quality was repeatedly declared to be a top target of Russian higher education general development. It is asserted that without that, to obtain competitive ability and technological sovereignty is impossible [1]. Herewith, it is to be noted that engineering staff training in Russia, as well as that in other education sectors, has been undergoing thorough reforms for the latest 25 years. That has resulted in a set of common negative trends pointed by experts, employers and students themselves: poor standards of enrolees, poor material and technological resources to maintain the programmes, and fails in adequacy of moulded acquirements to employers' requirements (although the quality of the engineering staff training is considered to differ [2]).

In a number of comparative investigations, the challenged processes in engineering education are noticed not only in Russia, but also in other countries [3, 4]. Particular attention is given to correlation of the enrolees' acquirements and educational progress up to finishing higher education [5]. An exploration is worth noticing, concerned to the quality of engineering education in BRICS countries, exposing a large disparity between the quality of elite and massive engineering educational programmes there. At the same time, the total number of engineering programmes graduates is considered to be a determinative

* Corresponding author: nikanorov@,zaobrazovanie.ru 
number in the global labour-market of high-technology spheres of economy [6]. It is to be noted that the content of the curricula and their quality management receive little attention.

\section{Analysis of Russian and international background}

In this context, it is critical to underscore that in Russian Federation, the education quality evaluation is particularly exposed with external tools, which is state system of education quality control above all - licensing, accreditation, independent quality assessment (also triggered and funded by state government authorities). As for professional and public accreditation and attainment certification, if they are provided by normative framework of higher education system and have had a definite success [7, 8], they are not fully implemented and still lie ahead for next ten years.

Russian Federation's mainstreaming into European Higher Education Area and signing the European Standards and guidelines for quality assurance in the European Higher Education Area (ESG) in 2015 has given a fresh impetus to the higher education development in Russian Federation. Standards related to internal evaluation of the education quality (eg, 1.3, 1.6, 1.9) provide the following principles: (1) "active role in creating the learning process", (2) necessity of sufficient "funding for learning and teaching activities" and accessibility of learning resources, (3) urgent need to carry monitoring continuously and to review degree programmes to make them correspond "to the needs of students and society", and need to communicate on the improvements "to all those concerned", and (4) the unity of the internal and the external education quality systems.

The implementation of the ESG student-centred principles noted above is impossible without formation of student communities aimed to evaluate and develop the education quality (including diversification of possible educational paths and development of various modes and ways to obtain formal, as well as informal education), to widen the students' estimation tools, and to form the mechanisms of incorporating this estimation into both external and internal education quality evaluation.

To speak about approaches to providing the internal assurance of the education quality in Russia, it is worth noting G. V. Andrushchak's paper on existing practices on the back of international ones [9]. It appears that Russian educational institutions, compared to Western ones, firstly, severely constricts a students' choice of educational path, relevant to their future career; secondly, lack an efficient practice of students' rating the teaching work in order to improve it [9]. Therewith, it is acknowledged that the essential factor of the efficiency of the mechanisms is proper motivation of the student community.

This paper was published before enactment of the Federal Law N 273 "Education in Russian Federation Act", which makes allowance for bodies that have a right to participate in the institution administration through representing a position of a group of educational relations actors. Thus, the students' participation is possible in case of their involving in governing bodies of educational institutions (Boards of Studies, supervisory boards, etc, including opportunities provided by institution Charter). Among the tools of involving the students in evaluation and development of education quality, an important one is procedure of self-examination of an educational institution, captured by section 29 of the Law.

It is also to be pointed out that, as distinct from the ESG, the "Education in Russian Federation Act" does not capture the internal evaluation of education quality, and this estimation refers to the competence of the educational institution itself. 


\section{The submitted pattern}

With reference to the above mentioned, the Education Quality Board of Youth Council of Ministry of Education and Science of the Russian Federation (hereafter - the Board) considers development of student self-government to be a necessary tool of internal evaluation of education quality. The Board submitted a conception of an on-going student union, with its activity being aimed to evaluate and develop the education quality (student board). An All-Russian youth project "Involving of Students of Higher Educational Institutions in Evaluation and Development of Education Quality High-Quality Education" (hereafter - the Project) has been triggered by the Board. The Project model is focused on synergistic interaction of the following actors: higher educational institution, public interest organisation, federal executive authority responsible for elaborating the state policy in the education sector or youth policy. The goal is to develop youth self-governance in educational institutions and to engage public interest organisations in continuous monitoring and control of education quality. The Project is implemented in a concerted effort by Ministry of Education and Science of the Russian Federation, the Education Quality commission of Youth affairs Council of the Ministry, and All-Russian public interest organisation "For the Quality of Education".

More than 6.000 students of 208 higher educational institutions from 70 member states of the Russian Federation are involved in the implementation of the Project. Apart from core activity of the unions, the member students are continuously being engaged in elearning (in MOOK format), and in exchanging "the best practices" in project activities, which enabled to form a social inter-academic student network united with common tasks and involved in project activities. The scope of tools using by them embraces the following.

(1) Integrated monitoring allows estimation the students' satisfaction of infrastructure, conditions of learning process functioning (equipment etc), internal learning process management (timetable, logistics etc), and general satisfaction of teaching staff. To carry the monitoring, a complex questionnaire is made (based on student standard) to be used once a semester.

(2) The scope of the second tool is limited by a single subject studying as a part of a degree programme. Subject monitoring, being carried at the end of each lecture / seminar, helps to evaluate clearness of lectures, a teacher's punctuality, social skills, using ICT, adequacy of studies content to the subject matter, orientation to declared acquirements to be obtained. Processing of the results can be used for making a student ranking of teachers, establishing the students' feedback and improving proposals for the teaching.

(3) Annual self-examination monitoring estimates the students' awareness of their own place in the institution. The results can be used to raise the purposefulness of the student engagement, to realise their expectations, and to establish the scope of information support sector. The questions touch on reasons the students have entered the institution, have chosen it and their special field, their career plans, subjects they want to study, learning results expected to be obtained. Also, their familiarity with Federal and local documents on their field of education and the regularity of preparations for studies is inquired.

(4) General monitoring results in observing general trends and dynamics of oscillations of the students' feelings about the learning process in the real-time mode. It should be carried on a regular basis - weekly or even daily - and contain the following questions: were the former day / week useful or not, have they learned anything new for this day / week, have they succeed to prepare for all the studies?

(5) With longitudinal explorations, changes of the same group of students' satisfaction are estimated for a definite period of time. Questions about changes of attitude to the necessity of disciplines, to activities of teaching staff, to practical trainings, being asked several times for extended period, allow creating more or less non-biased image of a 
discipline and its teaching. The survey should be conducted three times: in current semester: a semester later; after completing an externship or 3 to 6 months after employment in the profession during the upper years of studying of after graduation.

Thus, in the framework of the submitted pattern, a student community is considered to be an equal partner to the administration of the educational institution. The work product of the community can be used in a set of management procedures in the institutions.

\section{Conclusions}

The challenges of engineering education in Russia pointed by experts - comparably lower attainment level of enrolees, problems in material and technological resources maintaining the programmes, and the necessity to review the content of the curricula - actually seem to exist. As a solution, implementation of the mechanisms of internal evaluation along with external ones is suggested. Efficient involving of the students to the evaluation of the education quality would allow improving the competitive ability of the degree programmes and the efficiency of executive decision-making. That would make the programmes more flexible and oriented to employers and future graduates' interests.

\section{References}

1. Stenogramma zasedaniya soveta pri Prezidente Rossijskoj Federacii po obrazovaniyu $i$ nauke ot 23 iyunya 2014 goda. URL: http://kremlin.ru/events/president/news/45962 (2017) (In Russian)

2. L.M. Ogorodova, V.M. Kress, Yu.P. Pokholkov, Engineering Education 11, 2. (2012)

3. E. Kardanova, P. Loyalka, I. Chirikov, L. Liu, G. Li, H. Wang, E. Enchikova, H. Shi, N. Johnson, Assess Eval High Educ 41, 5 (2016)

4. P. Loyalka, M. Carnoy, I. Froumin, R. Dossani, J. B. Tilak, M. Dobryakova, Higher Education 68(6) (2014)

5. A. Light, W. Strayer, JHR 35, 2 (2000)

6. P. Loyalka, M. Carnoy, I. Froumin, R. Dossani, J. B. Tilak, The Quality of Engineering Education in the BRIC Countries (2013), URL: https://reap.fsi.stanford.edu/sites/default/files/Quality_of_engineering_education_in_the _BRIC_countries.pdf

7. Kriterii $i$ procedura professional'no-obshchestvennoj akkreditacii obrazovatel'nyh programm po tekhnicheskim napravleniyam i special'nostyam: informacionnoe izdanie (TPU 2014) (In Russian)

8 V. Ivanova, K. Mertins, S. Kaftasev, MATEC Web of Conferences 91, 01017 (2017)

9 G. V. Andrushchak, Voprosy ekonomiki, 6 (2007) (In Russian) 